\title{
“O CHÃO DA ALMA” E OUTRO POEMAS
}

Alex Pitta ${ }^{1}$

\section{O chão da alma}

De súbito, a amplidão acenou em mim a esperança, inundando o clarão a fraturar as sombras de meus olhos gastos de se fechar, que, por pouco, perdiam-se no estagnado.

Ignorada é a dor que antes trilhava desfiladeiros na turva jornada: a Morte, na velha carroça que em minhas mãos insistia, era a guia dessa densa noite de desterros.

Porém, interminável na vista, o planalto marca nos meus pés a indomável rota, resoluta e mística.

Eu, cego de luzes, sou envolvido pelo Tudo a firmar meus passos, sujos da grande terra fértil, tingida pelo vermelho do intenso sol.

Agora céu e chão - unidos no voo incerto e vivo - levam as areias do tempo (o mais esquecido longe), e eu, nos ventos da Iluminação, sigo para o mais inóspito solo que de verdes arboresce e de auroras avermelha-se:

a terra assentada em minha alma, desabitada no silêncio do desvisto e que, na sede de êxtases, abre-se, num claro peito, que em venturas planta-me num outro nascer, alado, incontido. O Infinito.

\footnotetext{
${ }^{1}$ Estudante de mestrado do Programa de Pós-Graduação em Literatura e Cultura da Universidade
} Federal da Bahia. alexpitta87@gmail.com 


\section{Sísifo aniquilado}

O insustentável claustro da dor cresce, enrijecendo ombros caídos de penar a própria andança em mundo vasto de montes feridos de largas distâncias.

Um espelho desenha-se na grande rocha, riscando a face cinza. Eram os olhos do perder e a vida vencida que subia, subia. Vencida. $\mathrm{E}$ as mãos, duras, apenas a rocha empurravam.

Havia o topo, do maior sol, iluminando o "se". Porém, curvado, o crânio suado vertia-se na ínfima força, em torturante penumbra. E as lágrimas escureciam-se na terra sem luz.

Os braços, gastos de ordem, tremiam o vazio a contrair músculos, ossos - e o peito. E a pedra era maior que o monte, que o sol que o sangue que desesperadamente escorria.

O ar faltava, tanto quanto o topo não visto.

Os olhos, embaçados, focavam, perdidos, o desfigurado reflexo. E Parada. A pedra. Congelado. Sísifo. No martírio ofício.

Viu-se nos dedos desanimados, na boca aberta e muda, nos ouvidos órfãos de pássaros. $\mathrm{E}$, nos rios vermelhos que cortavam sua face, viu a vida descer, feroz, sobre sua rasa alma. 


\section{Inocente}

“Acordar é um pouco de morrer."

Sonhando a deixar o doce colorir os passos, levava em si o berço de sua pequena aurora, pendurada em sóis plásticos de um brinquedo que no alto desenhava a cantiga a leve soar.

Eram os olhos fechados a ver o arco-íris, a dar à língua o gosto de viver, lambuzando dentes em sorrisos brancos de nuvens. E o sol, acima, girando, girando, na brisa do entardecer.

E fechados ficavam, sem saber do falso do sol, que sorria o opaco desenho de sua cor, frágil adorno a ninar um sono. Pequeno, ínfimo e profundo, pois não via o branco vácuo do acordar. 


\title{
O azul rúbeo
}

\author{
"O resto é soedá." \\ Manuel María, em Terra Cha
}

Todo o encanto que bebeu meu sangue, vertendo a oferta da alma em sujo chão, resta na seca carne, pálida, vagante na sede de um dia se encontrar no vermelho que resta.

E, ébrio de Nada, desfaço-me nos rastros da andança que dia algum existiu, indagando ao céu quaisquer auroras.

O vasto azul esvai-se vazio no tropeço da minha surdez de querer, que escorre a dor a tingir a terra e rasgar os pés já secos de norte. A visão perde-se na mistura das cores, na aquarela trágica do pôr-do-sol, e o ar mata a última gota de vida a agonizar num corpo esquecido de lágrimas.

O silêncio prolonga-se na aridez de só o vácuo enxergar.

No cromatismo da morte, alma e sol se vão, mentindo o mito do Retorno enquanto meus olhos, cegos, secos, encerram-se, como o peito.

Que se esquece na noite eterna.

Que se perde na infinda espera. 


\section{Imenso mar (ou O Tempo e o Eterno)}

Insistente no céu o cinza hostil irrompia enquanto a calma nadava no imenso mar, de raras vagas a girar com o alto vento, fronteirando frágil as gládias naturezas.

O Tempo banhava-se no horizonte azul, de ignorada fundura, fazendo sua misteriosa luz boiar infinita e ferir a fria cor do sombrio páramo, de náufraga aurora. Tirânico, o Eterno trovejava a noite de secas tormentas, com o perdido chovendo no mar o morto olvido.

O horizonte rachava-se no triste embate:

a fúria celeste cavava os vagalhões titânicos, golpeando com raios vácuos os braços do Tempo.

E, voando no ar, gritos do fogo e da procela.

O milenar paredão, cúmplice meu, murmura em mim a dor ecoada de suas fendas.

As areias, meu repouso, são a morte da grande rocha, escavadas pela amplidão das eras.

Sopros trazem a secura da guerra à pedra, cortando-lhe a pele, e rajadas de vazio descem do espaço, fazendo verter de um corpo morto as cinzas do Eterno cego.

Afundo-me na areia, incerto.

Com a face dura, impenetrável.

Descalço de fé, seco de unção, esquecido da Hora.

Lembrado somente pelo rochedo de cínzeo pó, cuja ossada é a cova aberta nas ruínas dos milênios onde enterro-me, ausente de mar, surdo de estrelas. 


\section{O palhaço}

“Amanhã recomeço."

Carlos Drummond de Andrade, em O elefante.

Riscada na fronte gasta,

a escassez do borrado sorrir

pela longa e só jornada.

Vermelha, a vergonha pintada

no nariz, de estranha forma,

recuando de olhares cinzas.

Amassado nas simples vestes,

dobra-se, na recusa de poder,

no bolso esquecido da sua vontade.

Os cabelos, enrolados no inusitado, desagradavam a ordem no desgrenho.

E o pente ria ridículos com dentes quebrados.

Os pés amarrados no sapato velho, enterrados na poeira dos dias vagos, e desfeitos do brilho dos saltos vivos.

Mãos grandes, desastradas, caíam nas coxas, por perdidas estarem no O-que-agarrar?, ritmando o olhar vagante e vazio a girar.

Sentado na longa estrada, espera. Espera.

Sonhando o maior truque, último, guardado num pequenino bolso, discreto:

vasculhando o interior do paletó, acha, 
roto e esgotado, um antigo estojo,

com seus lápis e pincéis de rosto.

Com mãos seguras, limpa da velha fronte a seca tinta que descascava em silêncios.

Despido de restos, olha o estojo, iluminado.

Pinta a ida a um Onde?, mapeado nos traços do arco-íris a agora emoldurar uma face que, tímida, esboça um sorriso, amarelo. Áureo.

$\mathrm{E}$ assim desenha-se, rascunhando felicidades.

O toque leve do pincel traz caretas e risos

e um vermelho outro aponta no grande nariz.

Sentado ainda, olha, com olhos de infância, o imenso vasto que o envolve. Então levanta e move-se, seguindo para seu destino. Pulando. 